\title{
The North Anatolian Fault Zone: an Evaluation of Earthquake Hazard Parameters
}

\author{
Yusuf Bayrak, Hakan Çınar and Erdem Bayrak \\ Karadeniz Technical University / Geophysics Department, Trabzon \\ Turkey
}

\section{Introduction}

Turkey is located in one of the most actively deforming regions in the world. The tectonic in and around Turkey depends on relative motions between the African, the Aegean, the Arabian, the Anatolian, the Black Sea and the Eurasian plates (Kasapoğlu \& Toksöz, 1983). The neotectonics of Turkey is governed by three major elements (Bozkurt, 2001): (1) the Aegean-Cyprean Arc, a convergent plate boundary where the African Plate to the south is subducting beneath the Anatolian Plate to the north; (2) the dextral North Anatolian Fault Zone; and (3) the sinistral East Anatolian Fault Zone. Also, the sinistral Dead Sea Fault Zone has an important role. The North Anatolian Fault Zone (NAFZ) is one of the best-known dextral strike-slip faults in the world because of its remarkable seismic activity, extremely well developed surface expression and importance for the tectonics of eastern Mediterranean region. The NAFZ is a dextral strike-slip fault system that extends from eastern Turkey in the east, to the north Aegean in the west. Along much of its length, this fault zone consists of a few shorter sub-parallel fault strands that sometimes display an anastomosing pattern (Bozkurt, 2001). To the east, the NAFZ forms a typical triple-junction and joins with the sinistral East Anatolian Fault Zone at Karlova. The NAFZ does not terminate at the Karliova triple junction, but continues towards south east.

The development of earthquake hazard assessment in Turkey has a substantial history and it has been produced considerable progress and innovation because Turkey has frequently suffered from major damaging earthquakes since the year $2000 \mathrm{BC}$. It has a long history of devastating earthquakes that have killed many thousands of people and caused economic loss, such as the İzmit $\left(M_{S}=7.8\right)$ and Düzce $\left(M_{S}=7.2\right)$ earthquakes of 17 August and 12 November 1999,respectively. As a result, a great number of local or regional earthquake hazard studies have been applied in recent years in order to present quantitative results on earthquake hazard of Turkey using the instrumental earthquake data. Several authors have used different statistical models to estimate the size of earthquake occurrences such as expected magnitude, intensity, ground acceleration, velocity or displacement. Amongst these studies are involving maximum seismic intensity, maximum magnitude and modal values (Bayrak et al., 2005, 2008a), peak ground acceleration (Erdik et al., 1999; Kayabalı \& Akın 2003), $\omega$-upper bound magnitude of GIII distribution (Bayrak et al., 2008b), the index K-value defined as relative earthquake hazard scale (Bayrak et al., 2009). 
Although many reports are known that Turkish instrumental and historical records are far from being incomplete for probabilistic approach of seismic hazard, a serious effort is undertaken for such analysis in the present work. For this reason, a method developed by Kijko \& Sellevoll $(1989,1992)$ has been carried out. The proposed approach is very flexible and provides several attractive properties. It accommodates the "gaps" in both historical and complete parts of the catalogue. It makes possible to estimate the maximum regional magnitude from the largest historical known earthquake, which occurred before the catalogues began. It allows the combination between the earthquakes of historical epoch and those which are extracted from short time periods of instrumental data. The complete part of the catalog can be divided into time intervals of different level of completeness. An illustration of the quality of the data, which can be used to obtain the seismic parameters through this approach, can be seen in Kijko \& Sellevoll (1992).

The earthquake hazard assessment requires the knowledge of the earthquake potential in a region. Qualitative techniques (epicenter maps, etc) as well as quantitative ones have been applied for presentation of the geographical distribution of earthquake hazard in several regions of the Earth and Turkey (e.g. Makropoulos, 1978; Tsapanos \& Papazachos, 1998; Hamdache et al., 1998; Tsapanos, 2001; Tsapanos, 2003; Bayrak et al., 2005). Common quantities considered as measures of seismicity are the maximum observed magnitude $M_{\max }$ (e.g. Yegulalp \& Kuo, 1974; Koravos et al., 2003; Ryall \& van Wormer, 1980), the annual number $N(M)$ or the mean return period $T_{m}$ of earthquakes (Comninakis, 1975) with magnitudes greater or equal to a given value $M$, etc. The knowledge of the return period is of great importance in studying and analyzing earthquake hazard and/or seismicity. It contributes with great importance to the determination of the national seismic code, according to which building if different categories (normal strategic, monumental) must be constructed; it conditions the priority of interventions on existing buildings (Hamdache et al., 1998). However, estimation of earthquake hazard involves the computation of long-term probabilities for the occurrence of earthquakes of a specified size in a given area during a given time interval (Mäntyniemi et al., 2004).

In this study, in order to estimate the maximum regional magnitude and the other related parameters such as the magnitude-frequency relationship, and the mean seismic activity rate a method introduced by Kijko \& Sellevoll (1989) is used. For this purpose, the technique of the maximum likelihood estimation is applied in the different regions of NAFZ on a basis of a procedure which utilizes data from both historical and instrumental files. The computations of the method are based on the assumptions of the Poisson occurrence of the earthquakes in time with a mean activity rate and the doubly truncated frequencymagnitude relation of Gutenberg-Richter. The standard deviations of these parameters are also estimated. Moreover, the mean return periods of the earthquakes with a certain lower magnitude, the most probable maximum magnitude of earthquakes in a given time interval, and the probability for a large earthquake occurrence are determined.

\subsection{The tectonics and seismicity of the North Anatolian Fault zone}

The North Anatolian Fault zone (NAFZ), one of the most seismoactive faults in the world, is a 1200-km-long and broad arc-shaped (Bozkurt, 2001) dextral strike-slip fault zone (Figure 1). NAFZ takes up the relative motion between the westward moving Anatolian Block, due mainly to the collision of the Arabian and African plates against the Eurasian and Anatolian ones (Sengör et al., 1985; Sengör et al., 2005), and Black Sea Plate (Şengör, 1979; Barka \& 
Kadinsky-Cade, 1988), and it forms a border between Eurasian and Anatolian plates. NAFZ was formed by progressive strain localization in a generally westerly widening right-lateral keirogen in northern Turkey mostly along an interface juxtaposing subduction-accretion material to its south and older and stiffer continental basements to its North (Şengör et al., 2005). Morphologically distinct and seismically active this fault extends from the Gulf of Saros in the northern Aegean Sea to the town of Karlıova (39॰18N, 41॰01E) in Eastern Turkey for $1200 \mathrm{~km}$, paralleling roughly the southern Black Sea shores and keeping a fairly regular distance of some $100 \mathrm{~km}$ to the coast, connecting the Aegean taphrogen (Şengör et al. 2005) with the East Anatolian high plateau (Koçyiğit et al. 2001; Şengör et al. 2003). This fault formed approximately 13 to $11 \mathrm{Ma}$ ago in the east and propagated westward. It reached the Sea of Marmara no earlier than $200 \mathrm{ka}$ ago, although shear related deformation in a broad zone there had already commenced in the late Miocene (Şengör et al., 2005). Along much of its lengths, NAFZ has well developed surface expressions and geological features such as a few shorter subparallel fault strands that sometimes display an anastomosing pattern, second order faults that splay from it into the Anatolian Plate, pull-apart basins, where there is an over-step along the fault trace (e.g.Niksar Basin, Taşova-Erbaa Basin, Erzincan Basin (Aydın\&Nur, 1982)), fault-wedge basins (e.g. Suşehri Basin, Gölova Basin, Vezirköprü Basin), complex pull-apart basins, bounded by an active strike-slip along one margin and a thrust fault along the other (e.g. Geyve Basin), composite pull-aparts, formed by coalescence of smaller pull-apart basins (e.g. Merzifon Basin, Suluova Basin, Erzincan Basin), and negative flower structure, bounded by strike-slip faults which show considerable amount of extension (e.g. Kazova basin along the Almus Fault Zone ) (Bozkurt, 2001). In the East the NAFZ starts around Karlıova triple junction, and it runs NW to Vezirköprü where it makes a left bend and continues westward. Around Karg1, it makes another left bend and then runs in a SWdirection (Bozkurt, 2001). Total offset of NAFZ is $85 \pm 5 \mathrm{~km}$ (Bozkurt, 2001; Şengör et al. 2003). Along most of the NAFZ, the right-lateral slip has a rate of $24 \pm 1 \mathrm{~mm} / \mathrm{yr}$ (McClusky et al., 2000; Flerit et al., 2004; Reilinger et al., 2006). This estimate is made by assuming that all motion of Anatolia is accommodated by slip on the North Anatolian fault, which serves as the primary boundary between Anatolia and Eurasia (Reilinger et. al., 1997; Reilinger et al., 2006). Focal mechanisms of the earthquakes along this fault zone give consistently pure right-lateral strike-slip solutions (Canitez\&Üçer, 1967; McKenzie, 1972; Jackson \& McKenzie, 1984; Eyidoğan et al., 1991; Barka, 1996).

Just east of the Marmara Sea, NAFZ splays into two major strands controlling and steering the tectonic regime of the Marmara region. These are the Northern Marmara strand and the Southern Marmara strand (Parsons, 2004). In the Marmara Sea, the NAFZ begins to lose its single fault line character and splays into a complex fault system (Erdik et al., 2004). The complexity of the NAFZ in this region may actually be related to the transition between an intermediate stress regime to the east and the extension regime which characterizes the Aegean Sea (Gürbüz et al., 2000). Northern Marmara strand consists of İzmit segment, Prince's Islands segment, and Ganos segment, from east to west respectively. The southern strand splits up again into a middle and southern branch, the former passing south of Iznik and the latter south of Bursa, by the Lakes of Apolyont and Manyas into the North Aegean extensional province (Ambraseys, 2002). Several marine-based geophysical surveys have been carried out in Marmara Sea in order to delineate fault systems of this region. The results obtained from these surveys are presented in the literature by Le Pichon et al. (1999, 2001, 2003), Imren et al. (2001), Demirbağ et al. (2003), Carton (2005), Carton et al. (2007), 
Laigle et al. (2008) and Becel et al. (2009). The Sea of Marmara is a large pull-apart that appears to have been a geometrical/mechanical obstacle encountered by the NAFZ during its propagation (Armijo et al., 2002, 2005). The pull-aparts of Marmara are Çınarcık, Central Marmara and Tekirdağ basins, from east to west respectively. These basins consist of several strike-slip and normal faults. GPS velocities suggest that the Anatolia/Eurasia motion is accommodated across the Marmara region by $18-20 \mathrm{~mm} / \mathrm{yr}$ of right-lateral slip and 8 $\mathrm{mm} / \mathrm{yr}$ of extension (Flerit et al., 2003, 2004).

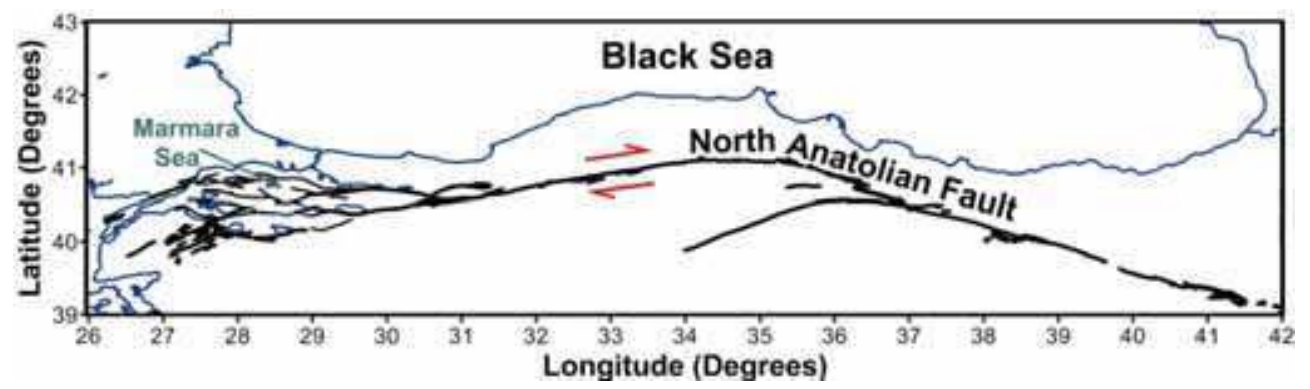

Fig. 1. Tectonic map of the North Anatolian Fault zone (modified from Şaroğlu, 1992; Le Pichon et al. 2003)

NAFZ has produced devastating earthquakes along its different sections in both historical and instrumental periods. The earthquakes of $M_{s} \geq 7.0$, used in this study, are listed in Table 1 and their epicentral distribution is shown in Figure 2. In instrumental period, the earthquakes in the NAFZ migrated from East to West. Beginning with 1939 Erzincan earthquake $\left(M_{S}=7.8\right)$, which produced about $350 \mathrm{~km}$ of ground rupture, the NAFZ ruptured, and formed more than $1000 \mathrm{~km}$ surface rupture along the fault in nine moderate large earthquakes $\left(\mathrm{M}_{\mathrm{S}}>6.7\right)$ (Bozkurt, 2001).

\subsection{Data, source zonation and completeness analysis}

The database and the seismicity data in this work were compiled from different sources and catalogues such as TURKNET, International Seismological Centre (ISC), Incorporated Research Institutions for Seismology (IRIS) and The Scientific and Technological Research Council of Turkey (TUBITAK) and provided in different magnitude scales. The catalogues contain the origin time, different magnitudes scales ( $m_{b}$-body wave magnitude, $M_{S}$-surface wave magnitude, $M_{L}$-local magnitude, $M_{D}$-duration magnitude, and $M_{W}$-moment magnitude), epicenter and depth information of earthquakes. Turkey earthquake catalogue, obtained from the Boğaziçi University, Kandilli Observatory and Earthquake Research Institute (KOERI), starts from 1974 until 2010. The earthquakes from 1900 to 1974 come from the International Seismological Centre (ISC) and instrumental catalogue of KOERI. The historical earthquake catalogue used in this study is taken from database of GSHAP (Global Seismic Hazard Assessment Program) being compiled by Erdik et al. (1999).

An earthquake data set used in seismicity or seismic hazard studies must certainly be homogenous, in other words it is necessary to use the same magnitude scale. But, the earthquake data obtained from different catalogues have been reported in different magnitude scales. So, all earthquakes must be defined in the same magnitude scale. Bayrak et al. (2009) developed some relationships between different magnitude scales ( $m_{b}$-body 
wave magnitude, $M_{S}$-surface wave magnitude, $M_{L}$-local magnitude, $M_{D}$-duration magnitude, and $M_{W}$-moment magnitude) in order to prepare a homogenous earthquake catalogue from different data sets. We prepared a homogenous earthquake data catalogue for $M_{S}$ magnitude using these relationships. The time interval considered for the present work changed between BC 1010 and AD 2010.

\begin{tabular}{|c|c|c|c|c|c|}
\hline Region No & Region Location & Date & Longitude & Latitude & $M_{S}$ \\
\hline \multirow[t]{4}{*}{1} & \multirow[t]{4}{*}{ Saroz Gulf } & 1010 & 27.00 & 40.60 & 7.4 \\
\hline & & 01.03 .1354 & 27.00 & 40.70 & 7.3 \\
\hline & & 05.08 .1766 & 27.11 & 40.74 & 7.6 \\
\hline & & 09.08.1912 & 27.20 & 40.60 & 7.3 \\
\hline \multirow[t]{3}{*}{2} & \multirow[t]{3}{*}{ Marmara Sea } & 18.10 .1343 & 28.30 & 40.80 & 7.5 \\
\hline & & 22.05 .1766 & 29.10 & 40.80 & 7.3 \\
\hline & & 10.07 .1894 & 28.70 & 40.60 & 7.0 \\
\hline \multirow[t]{5}{*}{3} & \multirow[t]{5}{*}{ İzmit-Düzce } & 25.05 .1719 & 29.58 & 40.66 & 7.0 \\
\hline & & 02.09 .1754 & 30.00 & 40.60 & 7.2 \\
\hline & & 22.07 .1967 & 30.69 & 40.67 & 7.1 \\
\hline & & 17.08.1999 & 29.99 & 40.70 & 7.8 \\
\hline & & 12.11.1999 & 31.21 & 40.74 & 7.2 \\
\hline 4 & The Southern Branch of NAF & & & & \\
\hline \multirow[t]{5}{*}{5} & \multirow[t]{5}{*}{ The Southern of Marmara } & 10.05 .1556 & 28.00 & 40.30 & 7.0 \\
\hline & & 06.03 .1737 & 26.60 & 39.80 & 7.2 \\
\hline & & 28.02 .1855 & 29.10 & 40.20 & 7.4 \\
\hline & & 11.04 .1855 & 29.20 & 40.20 & 7.0 \\
\hline & & 18.03.1953 & 29.49 & 40.01 & 7.2 \\
\hline \multirow[t]{3}{*}{6} & \multirow[t]{3}{*}{ Düzce-Tosya } & 26.11.1943 & 33.22 & 40.97 & 7.3 \\
\hline & & 01.02 .1944 & 33.20 & 41.10 & 7.3 \\
\hline & & 16.05 .1957 & 31.00 & 40.58 & 7.0 \\
\hline \multirow[t]{2}{*}{7} & \multirow[t]{2}{*}{ Tosya-Erbaa } & 1510 & 35.20 & 40.90 & 7.0 \\
\hline & & 20.12 .1942 & 36.35 & 40.66 & 7.1 \\
\hline \multirow[t]{2}{*}{8} & \multirow[t]{2}{*}{ Tokat-Erzincan } & 24.01.1916 & 36.83 & 40.27 & 7.1 \\
\hline & & 26.12 .1939 & 39.38 & 39.80 & 7.9 \\
\hline 9 & The Eastern of Erzincan & & & & \\
\hline
\end{tabular}

Table 1. The earthquakes with $\mathrm{M}_{s} \geq 7.0$ in the North Anatolian Fault zone 
A complete understanding of the historical and instrumental seismicity, tectonics, geology, paleoseismology, and other neotectonic properties of the considered region are necessary for an ideal delineation of seismic source zones. Several authors used different seismic source zones to study seismic hazard of Turkey (e.g., Alptekin, 1978; Erdik et al., 1999; Kayabalı, 2002; Bayrak et al., 2005; Bayrak et al., 2009). Bayrak et al. (2009) used different 24 source regions considering the different previous zonation studies for modeling of seismic hazard in Turkey and 3 seismic source zones in these 24 regions are related to NAFZ. In this study, we divided NAFZ into nine seismic zones for detailed study as seen in Figure 2. Also, these regions are listed in Table 1 . The epicentral distributions of the historical and instrumental earthquakes are shown in Figure 2 on different seismic source zones in NAFZ.

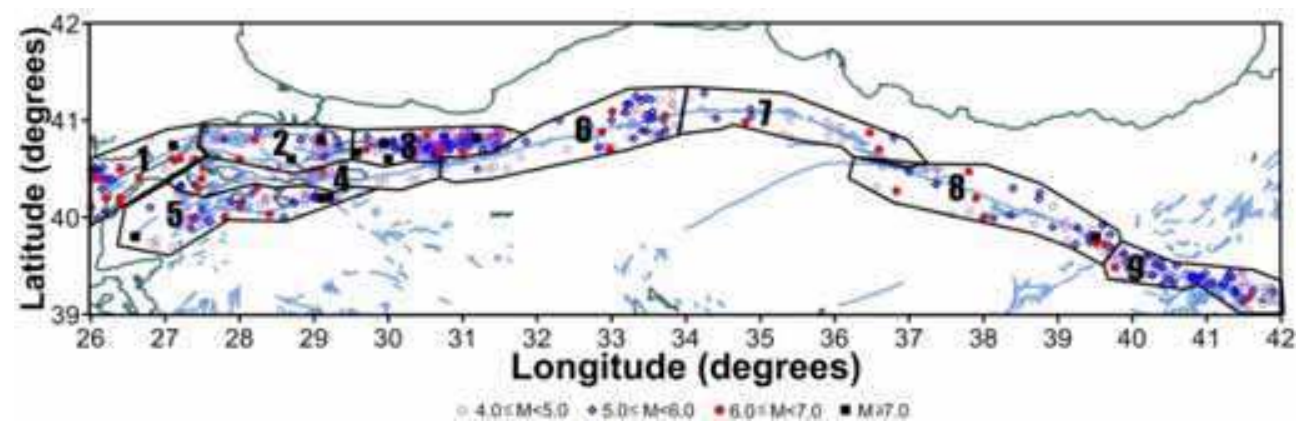

Fig. 2. Earthquake epicenter distribution and different 9 seismic regions in the North Anatolian Fault zone

It is frequently necessary to use a great number of events available for high-quality results in seismicity studies. The fact that magnitude completeness changes with time in most catalogues and usually decreases is well known. So, the minimum magnitude of completeness is an important parameter for seismicity studies. The catalogue used in this study encompasses the time period between BC 1010 and AD 2010 and this is the historical and instrumental parts of the catalogue. For the historical and instrumental periods, results of completeness analysis are made in this study are shown in Table 2 . The method used to assess the completeness of the data of this catalogue has been described in the literature (e.g., Tsapanos, 1990; Tsapanos \& Papazachos, 1998). The completeness was assessed on the basis of the cumulative frequency distribution of the magnitudes, and of the cumulative frequency distribution of the number of earthquakes with magnitudes larger than a certain value.

\begin{tabular}{|c|c|c|}
\hline Region & Period & Cut off Magnitude \\
\hline \multirow{3}{*}{1} & 1984 & $\mathrm{M}_{\mathrm{S}} \geq 2.1$ \\
& 1976 & $\mathrm{M}_{\mathrm{S}} \geq 3.2$ \\
& 1912 & $\mathrm{M}_{\mathrm{S}} \geq 4.1$ \\
& 1010 & $\mathrm{M}_{\mathrm{S}} \geq 6.2$ \\
\hline
\end{tabular}




\begin{tabular}{|c|c|c|}
\hline \multirow{4}{*}{2} & 1990 & $\mathrm{M}_{s} \geq 2.0$ \\
\hline & 1975 & $M_{s} \geq 3.0$ \\
\hline & 1942 & $\mathrm{M}_{s} \geq 4.3$ \\
\hline & 1296 & $M_{s} \geq 6.3$ \\
\hline \multirow{4}{*}{3} & 1988 & $M_{s} \geq 2.2$ \\
\hline & 1974 & $M_{s} \geq 3.0$ \\
\hline & 1907 & $\mathrm{M}_{s} \geq 4.2$ \\
\hline & 1719 & $M_{s} \geq 6.6$ \\
\hline \multirow{4}{*}{4} & 1993 & $\mathrm{M}_{\mathrm{s}} \geq 2.4$ \\
\hline & 1976 & $M_{s} \geq 3.5$ \\
\hline & 1935 & $\mathrm{M}_{\mathrm{s}} \geq 4.4$ \\
\hline & 1863 & $\mathrm{M}_{\mathrm{s}} \geq 6.4$ \\
\hline \multirow{4}{*}{5} & 1991 & $M_{s} \geq 2.3$ \\
\hline & 1977 & $M_{s} \geq 33$ \\
\hline & 1907 & $\mathrm{M}_{s} \geq 4.3$ \\
\hline & 1327 & $\mathrm{M}_{s} \geq 6.0$ \\
\hline \multirow{3}{*}{6} & 1999 & $M_{s} \geq 2.0$ \\
\hline & 1975 & $M_{s} \geq 3.2$ \\
\hline & 1918 & $\mathrm{M}_{S} \geq 4.0$ \\
\hline \multirow{4}{*}{7} & 1996 & $M_{s} \geq 2.0$ \\
\hline & 1978 & $M_{s} \geq 3.1$ \\
\hline & 1910 & $\mathrm{M}_{s} \geq 4.0$ \\
\hline & 1510 & $\mathrm{M}_{s} \geq 6.5$ \\
\hline \multirow{4}{*}{8} & 1995 & $M_{s} \geq 2.1$ \\
\hline & 1975 & $M_{s} \geq 3.1$ \\
\hline & 1904 & $\mathrm{M}_{s} \geq 4.0$ \\
\hline & 1165 & $M_{s} \geq 6.5$ \\
\hline \multirow{3}{*}{9} & 1995 & $M_{s} \geq 2.2$ \\
\hline & 1974 & $M_{s} \geq 3.3$ \\
\hline & 1907 & $\mathrm{M}_{s} \geq 4.0$ \\
\hline
\end{tabular}

Table 2. The results of completeness analysis for the different seismic regions in the North Anatolian Fault zone 


\subsection{Theoretical descriptions for the estimation of the earthquake hazard parameters}

Estimation of earthquake hazard parameters (maximum regional magnitude, $\hat{M}_{\max }$, earthquake activity rate $\hat{\lambda}$, and $b$ parameter in the Gutenberg-Richter equation) is extended to the case of mixed data containing large historical and recent instrumental events. The method accepts variable quality of complete data in different parts of a catalogue with different threshold magnitude values. The available earthquake catalogues usually contain two types of information: historical observations including major seismic events that occurred over a period of a few hundred years, and instrumental data for relatively short periods of time. The most suitable methods for analyzing the historical part of the catalogue are the extreme distributions, extended to allow varying time intervals from which maximum magnitudes are selected. Assuming that this part of catalogue contains only the largest seismic events, and having the possibility of dividing the catalogue into time intervals of different lengths, it can be in practice to analyze all the historical data. This method of incorporating the incomplete part of the catalogue into the analysis is very far from being optimum, as a great deal of information contained in small shocks is wasted (Kijko \& Sellevoll (1989). Another method for estimating the earthquake hazard parameters is to reject the historical parts that are incomplete and to use any standard method for the data from the other complete part of the catalogue. It is obvious that this procedure is also highly ineffective, as the quantitative assessment of recurrence of strong seismic events based on observations over a short period of time is burdened with large errors (Knopoff \& Kagan, 1977). This work presents a different approach, making it possible to combine the information contained in the historical part of the catalogue with that contained in the instrumental part of the catalogue.

The area-specific parameters that have to be determined are the area-specific mean seismic activity rate, the Gutenberg-Richter parameter and the maximum regional earthquake magnitude. In the present study, the maximum regional earthquake magnitude, $\hat{M}_{\max }$, is defined as the upper limit of the magnitude for the given seismic tectonic source (Reiter, 1990). The procedure for the evaluation of the maximum regional magnitude $\hat{M}_{\max }$ is based on the equation that compares the maximum observed magnitude $M_{\max }^{o b s}$ and the maximum expected magnitude $E\left(\hat{M}_{\max } / T\right)$ of the catalogue in the time interval $T$ (Kijko, 1988, 2004).

For the Gutenberg-Richter relation, a frequency-magnitude relation, the respective CDF (cumulative distribution function) of earthquake magnitudes which are bounded above by $M_{\max }^{\text {obs }}$ is given as:

$$
F_{M}\left(M \mid M_{\min }, M_{\max }^{o b s}\right)= \begin{cases}0 & \text { for } M<M_{\min }, \\ \frac{1-\exp \left[-\beta\left(M-M_{\min }\right)\right]}{1-\exp \left[-\beta\left(M_{\max }^{o b s}-M_{\min }\right)\right]}, & \text { for } M_{\min } \leq M \leq M_{\max }^{\text {obs }}, \\ 1, & \text { for } M>M_{\max }^{\text {obs }} .\end{cases}
$$

where $\beta=b \ln (10)$, and $b$ is the parameter of the Gutenberg-Richter relation.

From the condition that compares the largest observed magnitude $M_{\max }^{\text {obs }}$ and the maximum expected magnitude during a specified time interval $T$, we obtain, after integration by parts and simple transformations, the maximum regional magnitude $\hat{M}_{\max }$ (Kijko \& Graham, 1998): 


$$
\hat{M}_{\max }=M_{\max }^{o b s}+\int_{M_{\min }}^{M_{\max }^{o b s}}\left[F_{M}\left(M \mid M_{\min }, M_{\max }^{o b s}\right)\right]^{n} d M
$$

Further modifications of estimator (2) are straightforward. For example, following the assumption that the number of earthquakes occurring in unit time within a specified area obeys the Poisson distribution with parameter $\hat{\lambda}$, after replacing $n$ by $\hat{\lambda} T$, estimator (2) becomes:

$$
\hat{M}_{\max }=M_{\max }^{o b s}+\int_{M_{\min }}^{M_{\max }^{o b s}}\left[F_{M}\left(M \mid M_{\min }, M_{\max }^{o b s}\right)\right]^{\hat{\lambda} T} d M
$$

It is not difficult to show that the Gutenberg-Richter-based magnitude CDF (1), the estimator (2) takes the form (Kijko, 1988):

$$
\hat{M}_{\max }=M_{\max }^{o b s}+\frac{E_{1}\left(T z_{2}\right)-E_{1}\left(T z_{1}\right)}{\beta \exp \left(-T z_{2}\right)}+M_{\min } \exp (-\hat{\lambda} T)
$$

The above estimator of $\hat{M}_{\max }$ for doubly truncated Gutenberg-Richter relation was first obtained by Kijko (1988). The quantities in equation (4) are computed as: $Z_{1}=\hat{\lambda} A_{1} /\left(A_{1}-A_{2}\right), \quad Z_{2}=\hat{\lambda} A_{2} /\left(A_{1}-A_{2}\right), \quad A_{1}=\exp \left(-\beta M_{\min }\right), \quad A_{2}=\exp \left(-\beta M_{\max }^{\text {obs }}\right) \quad$ and $E_{1}($.$) denotes an exponential integral function (Abramowitz \& Stegum, 1970):$

$$
E_{1}(z)=\int_{z}^{\infty} \exp (-\zeta) / \zeta d \zeta
$$

From equations (3) and (4), the approximate variance of the maximum regional magnitude $\hat{M}_{\max }$, is equal to that derived by Kijko (2004):

$$
\operatorname{Var}\left(\hat{M}_{\max }\right)=\sigma_{M}^{2}+\left[\frac{E_{1}\left(T z_{2}\right)-E_{1}\left(T z_{1}\right)}{\beta \exp \left(-T z_{2}\right)}+M_{\min } \exp (-\hat{\lambda} T)\right]^{2}
$$

where $\sigma_{M}^{2}$ is the variance in the determination of the largest observed magnitude $M_{\max }^{o b s}$. It is assumed that the observed (apparent) magnitude is distorted by an observational error, which is distributed normally with a known standard deviation $\hat{\sigma}_{M}$ (Kijko \& Dessokey, 1987).

The parameters $\beta$ and $\hat{\lambda}$ for a given area are estimated by the maximum likelihood procedure described by Kijko \& Sellevoll $(1989,1992)$. This method allows for the utilization of all available seismicity information, as it makes use of an earthquake catalogue containing both incomplete historical observations and more congruous and complete instrumental data. Periods with gaps in the catalogue can also be taken into account. Equation (4) is applicable even in the cases where the considered magnitude interval, $M_{\max }-M_{\min }$, is short and the number of events small. Further details may be found in Kijko \& Sellevoll (1989).

The probability of a particular magnitude being exceeded in the area at least once during a specified time interval $t, H(M \mid t)$, and its associated mean return period $R P$ can give an indication of the level of seismic hazard in the area. 
Under the assumption that earthquakes with magnitude $M \geq M_{\min }$, follow a Poisson process with mean activity rate $\hat{\lambda}(M)=\hat{\lambda}_{A}\left[1-F_{M}(M)\right]$, where $\lambda_{A}$ is the area-specific mean seismic activity rate of earthquakes exceeding $M_{\min }$, we obtain:

$$
H(M \mid t)=1-\exp \left\{-\hat{\lambda}_{A} t\left[1-F_{M}(M)\right]\right\}
$$

and,

$$
R P(M)=\frac{1}{\hat{\lambda}_{A}\left[1-F_{M}(M)\right]}
$$

In (7), substituting $t=1$, we obtain the typical seismic hazard curve. Substituting for other values of $t$ (eg. 25,50,100,500), we obtain the probabilities of exceeding within the respective $t$.

The procedure is applied for the evaluation of the earthquake hazard potential in the NAFZ. For this purpose, we calculated the expected time interval for the occurrence of an earthquake, the most probable maximum magnitude of earthquakes in a given time period and the probability for an earthquake occurrence.

\section{Discussion and results}

In order to evaluate the earthquake hazard potential in the NAFZ using the historical and instrumental data, NAFZ is divided into different 9 source regions. The earthquake catalogue includes the time period between BC 1010 and AD 2010. The earthquake hazard has been assessed in terms of the maximum regional magnitude $\hat{M}_{\text {max }}$, the mean seismic activity rate $\hat{\lambda}$, the mean return period $R P$, probability for an earthquake occurrence $\operatorname{Pr}$ and the $b$ parameter of the magnitude-frequency relationship. The magnitude of the historical period earthquakes usually suffers from large errors which cause many problems in seismic hazard evaluation. In order to overcome this inconsistency Kijko \& Sellevoll $(1989,1992)$ introduced an alternative maximum likelihood approach, utilizing the information derived by any part of a data file including both historical and/or instrumental data. So, the earthquake hazard parameters, namely the maximum regional magnitude, $\hat{M}_{\max }$, activity rate of seismic events, $\hat{\lambda}$ and the $b$-values are obtained through the application of the Kijko \& Sellevoll $(1989,1992)$ approach. These earthquake hazard parameters estimated 9 different regions of NAFZ, listed in Table 3.

Regional variability of the maximum expected magnitudes for different 9 regions in NAFZ is shown in Figure 3. The estimated $\hat{M}_{\max }$ values are between 6.09 and 8.03. These values were distributed into four groups, smaller than 6.50, 6.50-7.00, 7.00-7.50 and greater than 7.50. These three groups of $\hat{M}_{\max }$ values are shown with different color scales, as shown in Figure 3. The values greater than 7.50 are found in regions $1,2,3,5$ and 8 . The largest $\hat{M}_{\max }$ value is calculated in and around Erzincan (region 8 with $\hat{M}_{\max }=8.03$ ), where the largest earthquake occurred in the instrumental period in 1939, with a maximum observed magnitude $M_{\max }^{\text {obs }}=7.90$. The other largest values of $\hat{M}_{\max }$ are calculated in the region between Kocaeli-Düzce (region 3 with $\hat{M}_{\max }=7.97$ ), where the largest event recently occurred in 1999 with $M_{\max }^{\text {obs }}=7.80$; in the west of the Marmara (region 1 with $\hat{M}_{\max }=7.72$ ), 
where the largest earthquake of the present century occurred in 1766 with a maximum observed magnitude of $M_{\max }^{o b s}=7.60$; in the Marmara (region 2 with $\hat{M}_{\max }=7.69$ ), where the largest earthquakes occurred in 1343 with $M_{\max }^{\text {obs }}=7.50$; in the south of Marmara (region 5 with $\hat{M}_{\max }=7.52$ ), where the largest earthquake occurred in 1855 , with a maximum observed magnitude $M_{\max }^{\text {obs }}=7.40$. The $\hat{M}_{\max }$ values changing between 7.00 and 7.49 are calculated in the 6 and 7 related to the central part of NAFZ located in Anatolia. The largest earthquakes in these regions are occurred in $1943\left(M_{\max }^{\text {obs }}=7.30\right)$ and $1942\left(M_{\max }^{\text {obs }}=7.10\right)$, respectively. The $\hat{M}_{\max }$ lower than 7.00 are related Region 4 and 9 . The largest earthquakes in these regions are lower than 6.40 and occurred in the instrumental period.

\begin{tabular}{|c|c|c|c|c|c|c|c|}
\hline Region & $M_{\max }^{\text {obs }}$ & $\hat{b}$ & $\sigma \hat{b}$ & $\hat{\lambda}$ & $\sigma \hat{\lambda}$ & $\hat{M}_{\max }$ & $\sigma \hat{M}_{\max }$ \\
\hline 1 & 7.60 & 0.74 & 0.02 & 20.53 & 3.37 & 7.72 & 0.23 \\
\hline 2 & 7.50 & 1.06 & 0.02 & 73.10 & 13.60 & 7.69 & 0.28 \\
\hline 3 & 7.80 & 0.79 & 0.01 & 52.30 & 8.60 & 7.97 & 0.26 \\
\hline 4 & 6.40 & 0.89 & 0.02 & 40.19 & 7.60 & 6.54 & 0.24 \\
\hline 5 & 7.40 & 0.78 & 0.02 & 33.41 & 5.57 & 7.52 & 0.23 \\
\hline 6 & 7.30 & 0.64 & 0.02 & 23.62 & 3.57 & 7.48 & 0.27 \\
\hline 7 & 7.10 & 0.69 & 0.03 & 10.68 & 1.62 & 7.22 & 0.23 \\
\hline 8 & 7.90 & 0.66 & 0.02 & 14.37 & 1.83 & 8.03 & 0.24 \\
\hline 9 & 6.00 & 0.65 & 0.02 & 27.321 & 4.06 & 6.09 & 0.13 \\
\hline
\end{tabular}

Table 3. Earhquake hazard parameters computed from Kijko method for the different seismic regions in the North Anatolian Fault zone. $M_{\max }^{\text {obs }}$ is observed maximum magnitude

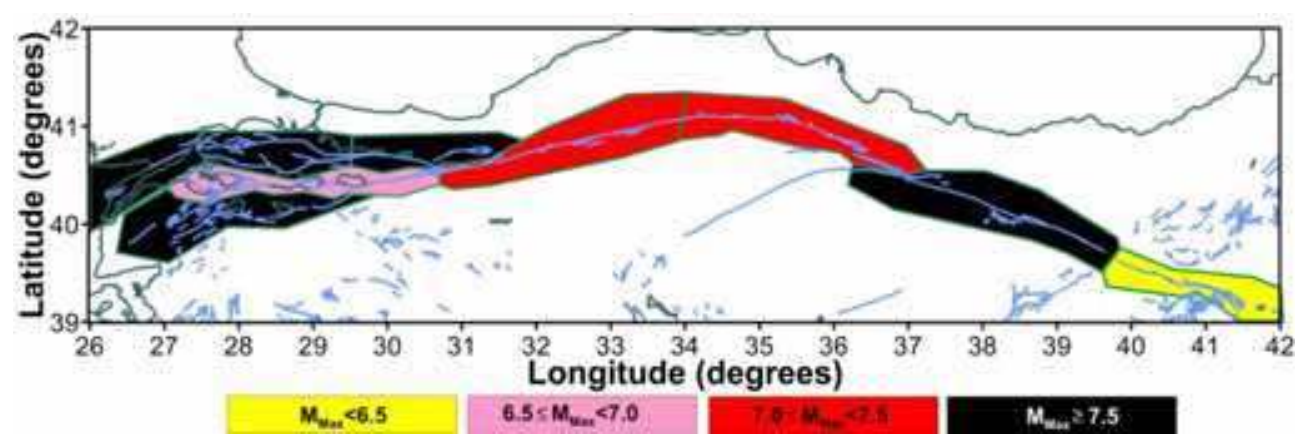

Fig. 3. $M_{\max }$ values computed Kijko method for the different 9 seismic regions in the North Anatolian Fault zone

The $b$-values for different 9 regions in NAFZ change between 0.64 and 1.06 . Computed $b$ values were distributed into four groups varying lower than $0.70,0.70-0.79,0.80-0.89$ and 
larger than 0.90. Figure 4 shows these four groups which is plotted with different color scale. The $b$-values greater than 0.70 are found in regions 1, 2, 3, 4 and 5 which are in and around Marmara Sea. The highest $b$-value in all regions is equal to 1.06 and computed in region 2 covering Marmara Sea. The b-values smaller than 0.70 are calculated in regions 6, 7, 8 and 9. These regions are located to Anatolian part of NAFZ. The lowest $b$-value in all regions is equal to 0.64 and computed in region 6 between Düzce and Tosya.

The $b$ parameter is considered to be closely related to tectonic characteristics of a region (Hatzidimitriou et al., 1985; Wang, 1988; Tsapanos, 1990). It seems to be in close connection with the geological age of an area (Allen et al., 1965). Tsapanos (1990) found significantly different $b$-values in east and west Pacific and suggested that this is related to the difference in the mechanical structure of the material in each area, as well as to their tectonic evolution. Manakou \&Tsapanos (2000) suggested that low $b$-values are related to low degree of heterogeneity, large strain rate, large velocity of deformation and therefore large fault. The $b$ parameter is considered to be closely related to tectonic characteristics of a region (Hatzidimitriou et al., 1985; Wang, 1988; Tsapanos, 1990). Scholz (1968) stated that low bvalues correspond to great stress and strain in a given region. This can be interpreted that this region is a promised one for an earthquake generation.

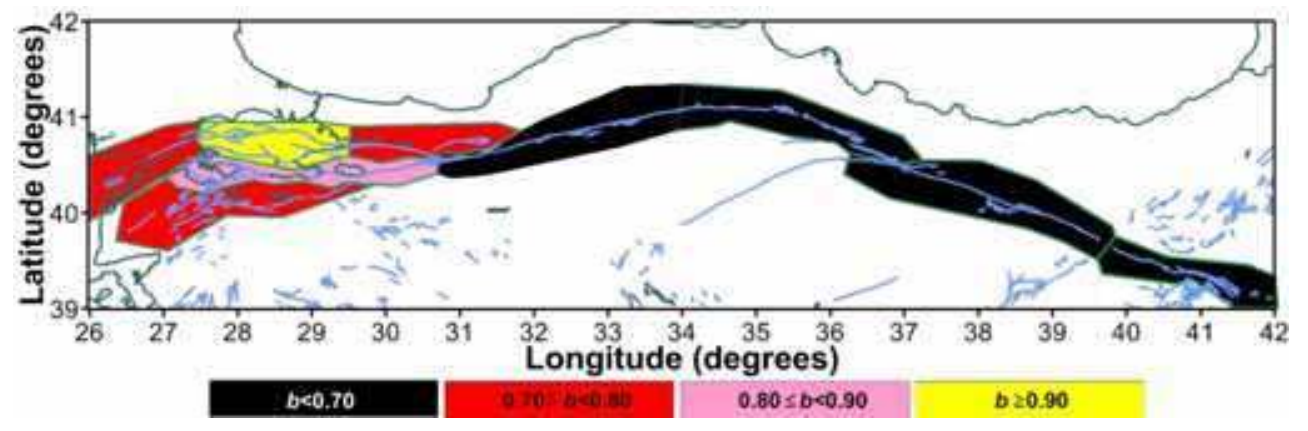

Fig. 4. $b$-values computed Kijko method for the different 9 seismic regions in the North Anatolian Fault zone

It is interesting that the $b$-values greater than 0.70 are related to Marmara region and the $b$ values lower than 0.70 are observed in Anatolian part of NAFZ. The $b$ values computed for different 9 regions of NAFZ reflect tectonic characteristics of the different parts of the fault. Along part of Anatolia of the NAFZ, the right-lateral slip has a rate of $24 \pm 1 \mathrm{~mm} / \mathrm{yr}$ (McClusky et al., 2000; Flerit et al., 2004; Reilinger et al., 2006). The regimes of right-lateral slip which has a rate of $18-20 \mathrm{~mm} / \mathrm{yr}$ and extension which has a rate of $8 \mathrm{~mm} / \mathrm{yr}$ dominate in the Marmara region (Flerit et al., 2003, 2004). The highest $b$-value in 9 regions of NAFZ is observed in the Marmara Sea named region 2 in this study. In the Marmara Sea, the NAFZ begins to lose its single fault line character and splays into a heterogeneous fault system because of large pull-apart. It is resulted that high $b$-values in regions 1, 2, 3, 4, and 5 located in and around Marmara Sea are related to pull-apart system, high degree of heterogeneity, low strain rate and low velocity of deformation.

The mean return periods $(R P)$ of earthquakes, with a certain magnitude, will not be exceeded in any year, are listed in Table 4 . Also, the earthquake hazard curves expressed in 
terms of the mean return period of earthquakes that are expected for the maximum observed magnitudes are shown in Figure 5. The lowest value of the mean return period for $M_{S} \geq 7.0$ is revealed in region 6 , having a value of 32.9 years. The second lower value is founded in region 3 as 35.0 years. The other regions with mean return periods which not exceeded 100 years for magnitude larger than or equal to 7.0 are the seismic regions: 1,5 and 8. The mean return periods in the other regions 2 and 7 are greater than 100 years and changes between 148.0 and 235.0 years. Since 1999 İzmit and Düzce earhquakes, it has intensively been debated that in the near future an earthquake greater than 7.0 would occur in the Marmara sea covering region 2. The last earthquake with magnitude of 7.0 occurred in this region in 1894. The main return period such an earthquake is found as 148.0 years in this study. According to our results, we would expect that an earthquake greater than 7.0 may take place between 2030 and 2050 in this region taking into account uncertainties. Although the debates are concentrated on the Marmara Sea, the seismic risk of occurrence for an earthquake with $M_{S} \geq 7.0$ in the region 6 is higher than that of Marmara Sea. We observed that the main return period such an earthquake is only 32.9 years and an earthquake with $M_{S} \geq 7.0$ in this region has not been occurred such an earthquake since 1957.

\begin{tabular}{|c|c|c|c|c|c|c|}
\hline \multicolumn{7}{|c|}{ Magnitüd } \\
\hline Region No & 5.0 & 5.5 & 6.0 & 6.5 & 7.0 & 7.5 \\
\hline 1 & 3.7 & 7.2 & 14.0 & 28.2 & 68.3 & 303.0 \\
\hline 2 & 4.4 & 9.9 & 22.5 & 53.3 & 148.0 & 844.0 \\
\hline 3 & 2.0 & 4.0 & 7.9 & 15.9 & 35.0 & 101.0 \\
\hline 4 & 5.6 & 12.4 & 32.1 & 83.9 & & \\
\hline 5 & 2.9 & 5.8 & 11.8 & 26.0 & 72.0 & 2550.0 \\
\hline 6 & 1.7 & 3.1 & 5.9 & 12.1 & 32.9 & \\
\hline 7 & 5.7 & 11.0 & 22.5 & 53.2 & 235.0 & \\
\hline 8 & 3.5 & 6.3 & 11.4 & 21.6 & 44.2 & 115.0 \\
\hline 9 & 2.1 & 5.35 & 47.0 & & & \\
\hline
\end{tabular}

Table 4. Earthquake return periods for magnitudes between 5.0-7.5 for the different seismic regions in the North Anatolian Fault zone

The probabilities $\left(P_{r}\right)$ are computed for a certain magnitude which will not be exceeded in 50 and 100 years are listed in Table 5. Also, the earthquake hazard curves expressed by the probability expected for earthquakes with the maximum observed magnitudes are plotted and shown in Figure 6.

As seen Table 5 and Figure 6, the probability of occurrence for the earthquakes with $M \geq 7.0$ is highest in region 6 covering area between Düzce and Tosya. In this region the probability of occurrence such an earthquake is $84 \%$ in the next 50 years. 

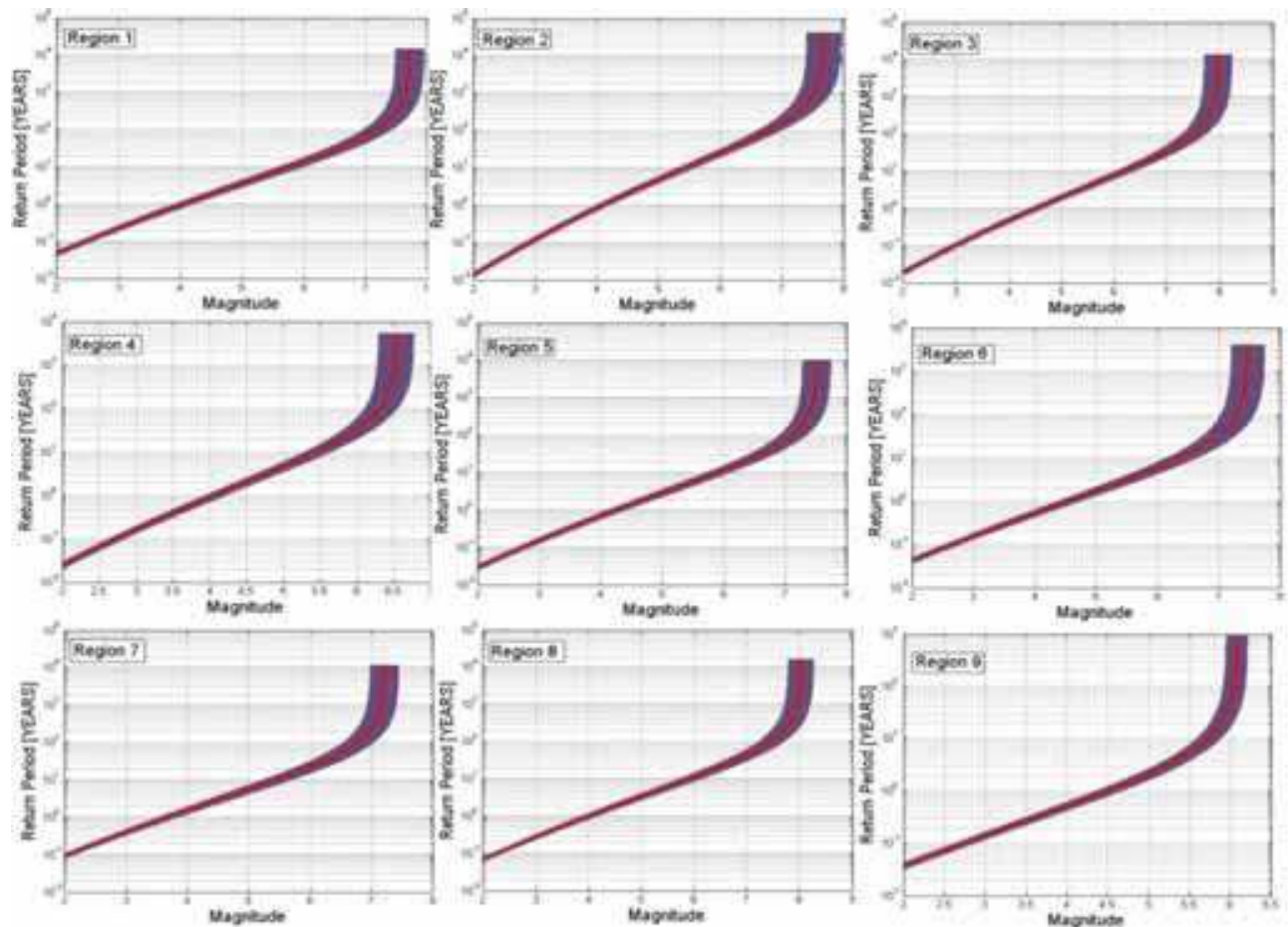

Fig. 5. Return period versus magnitudes for the different 9 seismic regions in the North Anatolian Fault zone

\begin{tabular}{|c|c|c|c|c|c|c|c|c|}
\hline \multirow{2}{*}{$\begin{array}{c}\text { Region } \\
\text { No }\end{array}$} & \multicolumn{2}{|c|}{6.0} & \multicolumn{2}{c|}{6.5} & \multicolumn{2}{c|}{7.0} & \multicolumn{2}{c|}{7.5} \\
\cline { 2 - 9 } & 50 & 100 & 50 & 100 & 50 & 100 & 50 & 100 \\
\hline 1 & 0.96 & 1.00 & 0.81 & 0.96 & 0.51 & 0.75 & 0.15 & 0.28 \\
\hline 2 & 0.85 & 0.97 & 0.63 & 0.85 & 0.27 & 0.46 & 0.06 & 0.11 \\
\hline 3 & 1.00 & 1.00 & 0.96 & 1.00 & 0.74 & 0.93 & 0.46 & 0.71 \\
\hline 4 & 0.77 & 0.94 & 0.08 & 0.15 & & & & \\
\hline 5 & 0.98 & 1.00 & 0.84 & 0.97 & 0.49 & 0.74 & 0.02 & 0.04 \\
\hline 6 & 0.99 & 1.00 & 0.97 & 1.00 & 0.84 & 0.97 & & \\
\hline 7 & 0.88 & 0.98 & 0.60 & 0.83 & 0.19 & 0.34 & & \\
\hline 8 & 0.98 & 1.00 & 0.85 & 0.97 & 0.66 & 0.88 & 0.35 & 0.57 \\
\hline 9 & 0.64 & 0.87 & & & & & & \\
\hline
\end{tabular}

Table 5. Earthquake probabilities versus magnitudes between 6.0-7.5 for 50 and 100 years for the different seismic regions in the North Anatolian Fault zone 

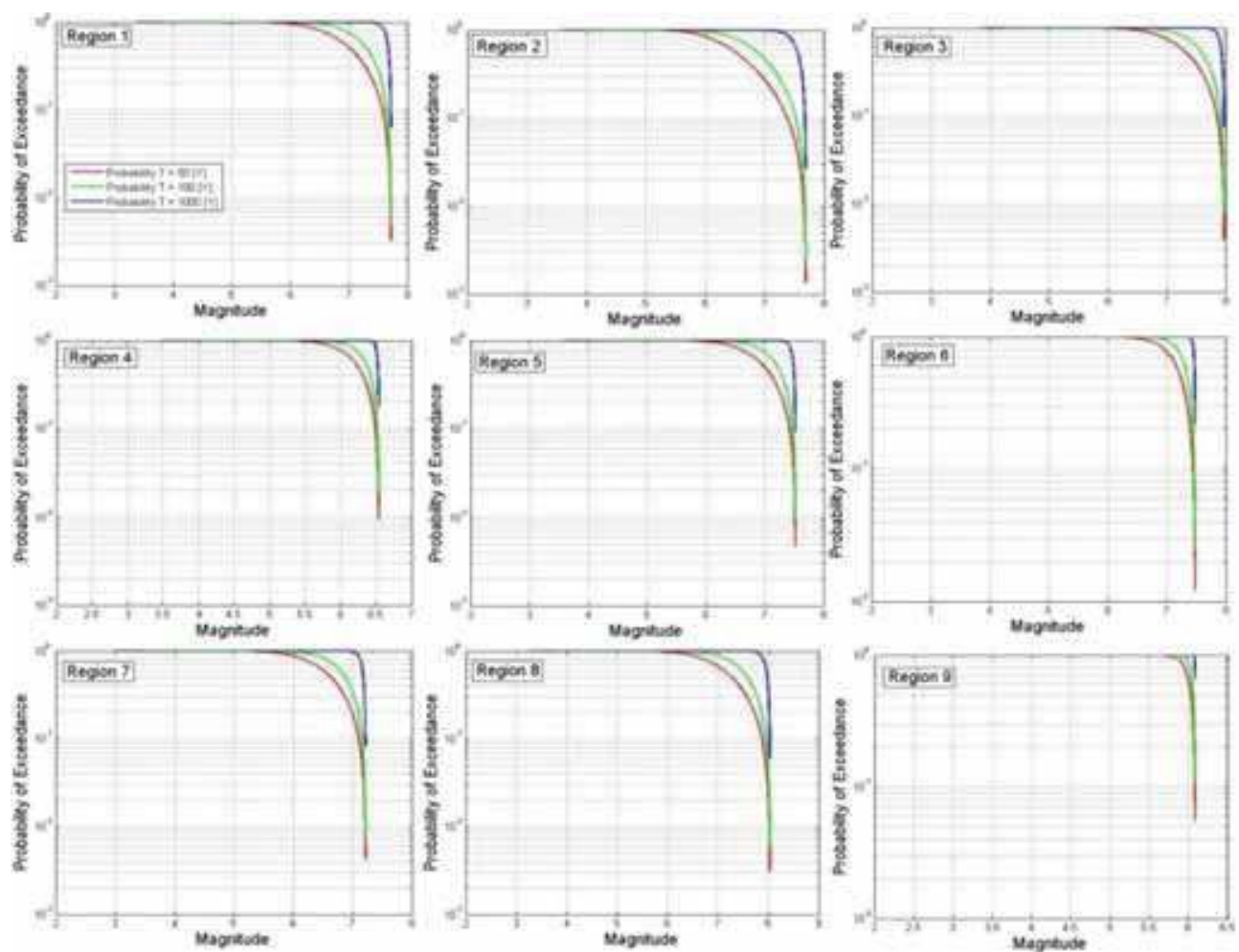

Fig. 6. Earthquake probabilities versus magnitudes for 50,100 and 1000 years for the different 9 seismic regions in the North Anatolian Fault zone

\section{Conclusions}

A combination of historical and instrumental earthquake catalogs was used to evaluate earthquake hazard potential for 9 different source regions of NAFZ. For this purpose, the maximum regional magnitude $\hat{M}_{\max }$, the mean seismic activity rate $\hat{\lambda}$, the mean return period $R P$, probability for an earthquake occurrence $\operatorname{Pr}$ and the $b$ parameter of the magnitude-frequency relationship are computed.

According to computed $\hat{M}_{\max }$ values, the largest earthquake occurrence potential on NAFZ is expected in and around Erzincan. The $b$-values exhibit two different clusters. While high $b$-values are found in regions 1, 2, 3, 4 and 5 which are in and around Marmara Sea due to pull-apart system and high degree of heterogenic faulting, low $b$-values are obtained in regions 6, 7, 8 and 9 which are located in Anatolian part of NAFZ showing homogenous faulting. The lowest $b$ value is observed between Düzce and Tosya where the mean return period is lowest and probability of occurrence for the earthquakes with $M_{S} \geq 7.0$ is highest. Although such a great earthquake is expected in the Marmara Sea in the near future, our results show that a great earthquake occurrence potential between Düzce and Tosya is higher than that of Marmara Sea. So, it should certainly be paid attention to this region. This 
study concludes that an earthquake greater than 7.0 may take place the dates between 2030 and 2050 in the Marmara Sea region which has intensively been debated by scientists.

\section{Acknowledgment}

The authors would like to express their sincere thanks to Prof. Dr. A. Kijko for providing computer program written in Matlab and the suggestions made in order for the paper to be improved. Also, they thank to Prof. Dr. T. M. Tsapanos for training the method used in this research.

\section{References}

Abramovitz M. \& Stegum I. R. (1970). Handbook of Mathematical Functions, 9th Edition. Dover Publ., New York, pp. 1046.

Allen, C. R.; P. S. \& Richter, C. F. \& Nordquist, J. M. (1965). Relation between seismicity and geological structure in southern California region, Bull. Seismol. Soc. Am., 55, 752797, 1965.

Ambraseys, N. (2002). The seismic activity of the Marmara Sea region over the last 2000 years. Bull. Seism. Soc. Am. 92, 1-18.

Armijo, R.; Meyer, B. \& Navarro, S. \& King, G. \& Barka, A. (2002). Asymmetric slip partitioning in the Sea of Marmara pull-apart: a clue to propagation processes of the North Anatolian Fault? Terranova 14, 80-86.

Armijo, R.; Pondard, N. \& Meyer, B. \& Uçarkus, G. \& Mercier de Lépinay, B. \& Malavieille, J. \& Dominguez, S. \& Gustcher, M.A. \& Schmidt, S. \& Beck, C. \& Catagay, N. \& Cakir, Z. \& Imren, C. \& Eris, K. \& Natalin, B. \& Ozalaybey, S. \& Tolun, L. \& Lefèvre, I. \& Seeber, L. \& Gasperini, L. \& Rangin, C. \& Emre, O. \& Sarikavak, K. (2005). Submarine fault scarps in the Sea of Marmara pullapart (North Anatolian Fault): Implications for seismic hazard in Istanbul. Gcube,Vol. 6, No.6, Q06009, doi:10.1029/2004GC000896.

Aydin, A. \& Nur, A. (1982). Evolution of pull-apart basins and their scale independence, Tectonics, 1, 91-105.

Alptekin, Ö. (1978). Magnitude-frequency relationships and deformation release for the earthquakes in and around Turkey. Thesis for Promoting to Associate Professor Level. Karadeniz Technical University, 107 pp. (in Turkish).

Barka, A. \& Kadinsky-Cade, K.(1988). Strike-slip fault geometry in Turkey and its influence on earthquake activitiy. Tectonics, 7, 663-684.

Barka, A. (1996). Slip distribution along the North Anatolian Fault associated with the large earthquakes of the period 1939 to 1967. Bull. Seismol. Soc. Am. 86:1238-1254.

Bayrak, Y.; Y1lmaztürk, A. \& Öztürk, S. (2005). Relationships between fundamental seismic hazard parameters for the different source regions in Turkey. Natural Hazards 36: 445-462.

Bayrak, Y.; Öztürk, S. \& Koravos, G.Ch. \& Leventakis, G.A. \& Tsapanos, T.M. (2008a). Seismicity assessment for the different regions in and around Turkey based on instrumental data: Gumbel first asymptotic distribution and Gutenberg-Richter cumulative frequency law. Natural Hazards and Earth System Sciences 8: 109-122.

Bayrak, Y.; Öztürk, S. \& Çınar, H.\& Koravos, G.Ch. \& Tsapanos, T.M. (2008b). Regional variation of the $\omega$-upper bound magnitude of GIII distribution in and around 
Turkey: Tectonic implications for earthquake hazards. Pure and Applied Geophysics 165: 1367-1390.

Bayrak, Y.; Öztürk, S. \& Çınar, H. \& Kalafat, D. \& Tsapanos, T.M. \& Koravos, G.Ch. \& Leventakis, G.A. (2009). Estimating earthquake hazard parameters from instrumental data for different regions in and around Turkey. Engineering Geology 105: 200-210.

Becel, A.; Laigle,M. \& de Vood, B. \& Hirn, A. \& Taymaz, T.\& Galve, A.\& Shimamura, H.\& Murai, Y. \& Lepine, J-C. \& Sapine, M. \& Özalaybey, S. (2009). Moho, crustal architecture and deep deformation under the North Marmara trough, from the SEISMARMARA Leg1 offshore-onshore reflection-refraction survey, Tectonophysics, $467,1-21$.

Bozkurt, E. (2001). Neotectonics of Turkey- a Synthesis. Geodinamica Acta, 14, 3-30.,

Canitez, N. \& Üçer, B. (1967). Computer determinations for the fault plane solutions in and near Anatolia. Tectonophysics, 4, 235-244.

Carton, H. (2005). Three-dimensional seismic images of an active-pull apart basin: the Cinarcik Basin along the North Anatolian Fault. Lithos Sci Rep 7:63-72

Carton, H.; Singh, S.C. \& Hirn, A. \& Bazin, S. \& de Voogd, B. \& Vigner, A. \& RIcolleau, A. \& Cetin, S. \& Oçakoglu, N. \& Karakoç, F.\& Sevilgen, V.(2007). Seismic imaging of the three-dimensional architecture of the Cinarcik Basin along the North Anatolian Fault. J.Geophys. Res. 112, 1-17. doi:10.1029/2006JB004548 B06101.

Comninakis, PE. (1975). Contribution to the study of the seismicity of Greece. PhD Thesis, University of Athens, 110pp.

Demirbağ, E.; Rangin, C. \& Le Pichon, X. \& Sengor, A.M.C. (2003). Investigation of the tectonics of the Main Marmara Fault by means of deep-towed seismic data. Tectonophysics 361, 1-19.

Erdik, M. ; Alpay, BY. \& Onur, T. \& Sesetyan, K. \& Birgoren, G. (1999). Assessment of earthquake hazard in Turkey and neighboring regions. Annali di Geofisica 42: 11251138.

Erdik, M.; Demircioğlu, M. \& Sesetyan, K. \& Durukal, E. \& Siyahi, B. (2004). Earthquake hazard in Marmara region, Turkey. Soil Dynamics and Earthquake Engineering, 24, 605-631.

Eyidoğan, H.; Utku, Z. \& Güçlü, U. \& Değirmenci, E. (1991). Türkiye Büyük Depremleri Makro-Sismik Rehberi (1900-1988). İstanbul Tek.Univ. Maden Fak., Jeofizik Mühendisliği Bölümü, [II]+198 pp.

Flerit, F.; Armijo, R. \& King, G.C.P. \& Meyer, B. \& Barka, A. (2003). Slip partitioning in the Sea of Marmara pull-apart determined from GPS velocity vectors. Geophys. J. Int. 154, 1-7.

Flerit,F.; Armijo, R. \& King, G. \& Meyer, B. (2004). The Mechanical interaction between the propagating North Anatolian Fault and the back-arc extension in the Aegean, Earth Planet. Sci. Lett., 224, 347-362.

Gürbüz, C.; Aktar, M. \& Eyidoğan, H. \& Cisternas, A. \& Haessler, H. \& Barka, A. \& Ergin, M. \& Türkelli, N. \& Polat, O. \& Üçer, S.B. \& Kuleli, S. \& Barış, S. \& Kaypak, B. \& Bekler, T. \& Zor, E. \& Biçmen, F. \& Yörük, A. (2000). The seismotectonics of the Marmara region (Turkey): results from a microseismic experiment. Tectonophysics $316,1-17$. 
Hamdache, M.; Bezzeghoud, M. \& Mokrane, A. (1998). Estimation of seismic hazard parameters in the northern part of Algeria. Pure and Applied Geophysics 151: 101-117.

Hatzidimitriou, P. M.; Papadimitriou, E. E. \& Mountrakis, D. M. \& Papazachos, B. C. (1985). The seismic parameter $\mathrm{b}$ of the frequency-magnitude relation and its association with geological zones in the area of Greece, Tectonophysics, 120, 141-151, 1985.

İmren, C.; Le Pichon, X. \& Rangin, C. \& Demirbağ, E. \& Ecevitoğlu, B. \& Gorur, N. (2001). The North Anatolian fault within the Sea of Marmara: A new interpretation based on multi-channel seismic and multi-beam bathymetry data, Earth Planet. Sci. Lett., 186, 143-158,

Jackson, J. \& McKenzie, D. (1984). Active Tectonics of the Alpine-Himalayan Belt between western Turkey and Pakistan. Geophys. J.R. Astr.Soc., 77,185- 264.

Koravos, G.; Main, I. \& Tsapanos, TM. \& Musson, RMW. (2003). Maximum earthquake magnitudes in the Aegean area constrained by tectonic moment release rates. Geophysical Journal International 152: 94-112.

Kasapoglu, EK. \& Toksöz, M.N. (1983). Tectonic consequences of the collision of the Arabian and Eurasian plates: finite element models. Tectonophysics 100: 71-95.

Kayabalı, K. (2002). Modeling of seismic hazard for Turkey using the recent neotectonic data. Engineering Geology 63, 221-232.

Kayabali, K. \& Akin, M. (2003). Seismic hazard map of Turkey using the deterministic approach. Engineering Geology 69: 127-137.

Koçyiğit, A.; Rojay, B. \& Cihan, M. \& Özacar, A. (2001). The June 6, 2000, Orta (Çankırı, Turkey) earthquake: sourced from a new antithetic sinistral strike-slip structure of the North Anatolian Fault System, the Dodurga Fault Zone. Turkish Journal of Earth Sciences, 10, 69-82.

Kijko, A. \& Dessokey, M.M. (1987). Application of extreme magnitude distributions to incomplete earthquake files. Bulletin of the Seismological Society of America 77: 14291436.

Kijko, A. (1988). Maximum likelihood estimation of Gutenberg-Richter b parameter for uncertain magnitudes values. Pure and Applied Geophysics 127: 573-579.

Kijko, A. \& Sellevoll, M.A. (1989). Estimation of earthquake hazard parameters from incomplete data files. Part I. Utilization of extreme and complete catalogs with different threshold magnitudes. Bulletin of the Seismological Society of America 79: 645-654.

Kijko, A. \& Sellevoll, M.A. (1992). Estimation of earthquake hazard parameters from incomplete data files, Part II: Incorporation of magnitude heterogeneity. Bulletin of the Seismological Society of America 82: 120-134.

Kijko, A. \& Graham, G. (1998). Parametric-historic procedure for probabilistic seismic hazard analysis, Part I: Estimation of maximum regional magnitude $\mathrm{M}_{\max }$. Pure and Applied Geophysics 152, 413-442.

Kijko, A. (2004). Estimation of the maximum earthquake magnitude $\mathrm{M}_{\max }$. Pure and Applied Geophysics 161: 1-27.

Knopoff, L. \& Kagan, Y. (1977). Analysis of the theory of extremes as applied to earthquake problems. Journal of Geophysical Research 82: 5647-5657.

Laigle, M.; Bécel, A. \& de Voogd, B. \& Hirn, A. \& Taymaz, T. \& Ozalaybey, S \& the Members of the SEISMARMARA Leg1.( 2008). A first deep seismic survey in the Sea of Marmara:whole crust and deep basins. Earth Planet. Sci. Lett. 270, 168-179. 
Le Pichon, X.; Taymaz, T. \& Şengör, A.M.C. (1999). The Marmara Fault and the future Istanbul earthquake, in International Conference on the Kocaeli Earthquake, 17 August 1999, edited by M. Karaca and D. N. Ural, pp. 41-54, Istanbul Tech. Univ. Press House, Istanbul, Turkey.

Le Pichon, X.; Sengor, A.M. C. \& Demirbag, E. \& Rangin, C. \& Imren, C. \& Armijo, R. \& Görür, N. \& Çağatay, N. \& Mercier de Lépinay, B. \& Meyer, B. \& Saatcilar, R. \& Tok, B. (2001). The active Main Marmara fault, Earth Planet.Sci. Lett., 192, 595-616.

Le Pichon, X.; Chamot-Rooke, N. \& Rangin, C. \& Sengör, A.M.C. (2003). The North Anatolian fault in the Sea of Marmara. J. Geophys. Res. 108 (B4), 2179.

Makropouos, K.C. (1978). The statistics of large earthquake magnitude and an evaluation of Greek seismicity, PhD Thesis, University of Edinburgh, Edinburgh, 193 pp.

Manakou, MV. \& Tsapanos, T.M. (2000). Seismicity and seismic hazard parameters evaluation in the island of Crete and the surrounding area inferred from mixed files. Tectonophysics 321: 157-178.

Mäntyniemi, P.; Tsapanos, T.M. \& Kijko, A. (2004). An estimate of probabilistic seismic hazard for five cities in Greece by using the parametric-historic procedure. Engineering Geology 72: 217-231.

Mc Clusky, S.; Balassanian, S. \& Barka, A. \& Demir, C. \& Ergintav, S. \& Georgiev, I. \& Gurkan, O. \& Hamburger, M. \& Hurst, K. \& Kahle, H. \& Kastens, K. \& Kekelidze, G. \& King, R. \& Kotzev, V. \& Lenk, O. \& Mahmoud, S. \& Mishin, A. \& Nadariya, M. \& Ouzounis, A. \& Paradissis, D. \& Peter, Y. \& Prilepin, M. \& Reilinger, R. \& Sanli, I. \& Seeger, H. \& Tealeb, A. \& Toksoz, M.N. \& Veis, G. (2000). Global Positioning system constraints on plate kinematics and dynamics in the eastern Mediterranean and Caucasus. Journal of Geophysical Research, 105, B3, 5695-5719.

McKenzie, D.P. (1972). Active tectonics of the Mediterranean region, Geophys. J.R.Astron. Soc., 30, 109-185.

Parsons, T. (2004). Recalculated probability of $M \geq 7$ earthquakes beneath the Sea of Marmara, Turkey. Journal of Geophysical Research, vol. 109, B05304, doi: 10. 1029 / 2003 JB 002667.

Reilinger, R.E.; McCLusky, S. \& Oral, M.B. \& King, R.W. \& Toksoz, M.N. (1997). Global Positioning System measurements of present-day crustal movements in the ArabiaAfrica- Eurasia plate collision zone. Journal of Geophysical Research,102:9983-9999.

Reilinger,R.; McClusky,S. \& Vernant,P. \& Lawrence,S. \& Ergintav,S. \& Cakmak,R. \& Özener,H. \& Kadirov,F. \& Guliev,I. \& Stepanyan,R. \& Nadariya,M.\& Hahubia,G. \& Mahmoud,S. \& Sakr, K. \& ArRajehi,A. \& Paradissis, D. \& Al-Aydrus, A. \& Prilepin, M. \& Guseva,T. \& Evren, E. \& Dmitrotsa, A. \& Filikov, S.V. \& Gomez, F. \& Al-Ghazzi, R. \& Karam,G. (2006). GPS constraints on continental deformation in the Africa-Arabia- Eurasia continental collision zone and implications for the dynamics of plate interactions. Journal of Geophysical Researchs. VOL. 111, B0541, doi:10.1029/2005JB004051.

Ryall, A.S. \& Van Wormer, JD. (1980). Estimation of maximum magnitude and recommended seismic zone changes in the western great basin. Bulletin of the Seismological Society of America 70: 1573-1581.

Scholz, C.H. (1968). The frequency-magnitude relation of microfracturing in rock and its relation to earthquakes, Bull. Seism. Soc. Am., 58, 399-415, 1968. 
Şaroğlu, F.; Emre, O. \& Kuş̧̧u, I. (1992). Active fault map of Turkey. General Directorate of Mineral Research and Exploration, Ankara, Turkey

Şengör, A.M.C. (1979). The North Anatolian transform fault: its age, offset and tectonic significance. Journal of the Geological Society of London 136, 269-282.

Şengör, A.M.C.; Görür, N. \& Şaroğlu, F. (1985). Strike-slip faulting and related basin formation in zones of tectonic escape: Turkey as a case study, The Society of Economic Paleontologists and Mineralogists, Special Publication, 37, 227-264.

Şengör, A.M.C.; Özeren, S. \& Genc, T. \& Zor E. (2003). East Anatolian high plateau as a mantle-supported, north-south shortened domal structure. Geophys. Res. Lett. 30: 8045.

Şengör, A.M.C.; Tüysüz, O. \& İmren, C. \& Sakınç, M. \& Eyidoğan, H. \& Görür, N. \& Le Pichon, X. \& Rangin, C. (2005). The North Anatolian Fault: A New Look. Annual Review of Earth and Planetary Sciences, 33, 37-112.

Tsapanos, T.M. (1990). b-values of two tectonic parts in the circum-Pacific belt. Pure and Applied Geophysics 134: 229-242.

Tsapanos, T.M. \& Papazachos, BC. (1998). Geographical and vertical variation of the earth's seismicity. Journal of Seismology 2: 183-1998.

Tsapanos, T.M. (2001). Evaluation of seismic hazard parameters for selected regions of the world: the maximum regional magnitude. Annali di Geofisica 44: 69-79.

Tsapanos, T.M. (2003). Appraisal of seismic hazard parameters for the seismic regions of the east Circum-Pasific belt inferred from a Bayesian approach. Natural Hazards 30: 5978.

Wang, J. H. (1988). b-values of shallow earthquakes in Taiwan, Bull. Seismol. Soc. Am., 78, 1243-1254, 1988.

Yegulalp, TM. \& Kuo, JT. (1974). Statistical prediction of occurrence of maximum magnitude earthquakes. Bulletin of the Seismological Society of America 64: 393-414. 


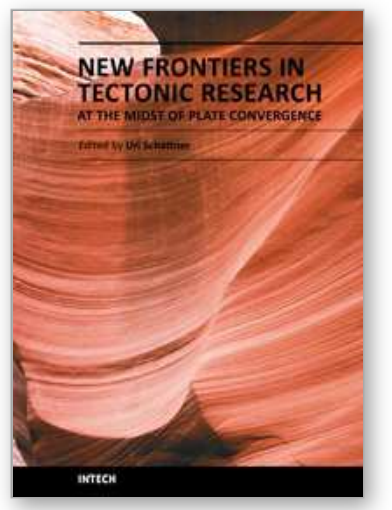

\section{New Frontiers in Tectonic Research - At the Midst of Plate Convergence}

Edited by Dr. Uri Schattner

ISBN 978-953-307-594-5

Hard cover, 352 pages

Publisher InTech

Published online 09, August, 2011

Published in print edition August, 2011

Ocean closure involves a variety of converging tectonic processes that reshape shrinking basins, their adjacent margins and the entire earth underneath. Following continental breakup, margin formation and sediment accumulation, tectonics normally relaxes and the margins become passive for millions of years. However, when final convergence is at the gate, the passive days of any ocean and its margins are over or soon will be. The fate of the Mediterranean and Persian Gulf is seemingly known beforehand, as they are nestled in the midst of Africa-Arabia plate convergence with Eurasia. Over millions of years through the Cenozoic era they progressively shriveled, leaving only a glimpse of the Tethys Ocean. Eventually, the basins will adhere to the Alpine-Himalaya orogen and dissipate. This book focuses on a unique stage in the ocean closure process, when significant convergence already induced major deformations, yet the inter-plate basins and margins still record the geological history.

\section{How to reference}

In order to correctly reference this scholarly work, feel free to copy and paste the following:

Yusuf Bayrak, Hakan Çınar and Erdem Bayrak (2011). The North Anatolian Fault Zone: an Evaluation of Earthquake Hazard Parameters, New Frontiers in Tectonic Research - At the Midst of Plate Convergence, Dr. Uri Schattner (Ed.), ISBN: 978-953-307-594-5, InTech, Available from: http://www.intechopen.com/books/newfrontiers-in-tectonic-research-at-the-midst-of-plate-convergence/the-north-anatolian-fault-zone-an-evaluationof-earthquake-hazard-parameters

\section{INTECH}

open science | open minds

\section{InTech Europe}

University Campus STeP Ri

Slavka Krautzeka 83/A

51000 Rijeka, Croatia

Phone: +385 (51) 770447

Fax: +385 (51) 686166

www.intechopen.com

\section{InTech China}

Unit 405, Office Block, Hotel Equatorial Shanghai

No.65, Yan An Road (West), Shanghai, 200040, China

中国上海市延安西路 65 号上海国际贵都大饭店办公楼 405 单元

Phone: +86-21-62489820

Fax: $+86-21-62489821$ 
(C) 2011 The Author(s). Licensee IntechOpen. This chapter is distributed under the terms of the Creative Commons Attribution-NonCommercialShareAlike-3.0 License, which permits use, distribution and reproduction for non-commercial purposes, provided the original is properly cited and derivative works building on this content are distributed under the same license. 